DOI: $10.1355 / \mathrm{ae} 26-1 \mathrm{~h}$

\title{
Vietnam after Two Years of WTO Accession What Lessons Can Be Learnt?
}

\author{
Vo Tri Thanh and Nguyen Anh Duong
}

\begin{abstract}
This paper provides an overview of the socio-economic changes in Vietnam since its WTO accession in early 2007. This is critical since ex ante studies have all seemed to significantly underestimate the impacts of WTO accession and integration on Vietnam's economy, whilst failing to rigorously analyse foreign capital inflows and related macroeconomic issues. The years 2007-2008 witnessed remarkable improvements in Vietnam's economic performance, from real aspects to social issues and economic institutions. However, quality of growth remained modest, trade deficit widened, inflation surged, while Vietnam's vulnerability to negative external shocks gets increasingly apparent. The paper then draws out several major lessons for Vietnam from its first two years of WTO membership. Areas for further improvements, such as resolutions of bottlenecks to strengthening competitiveness, sustaining development, and building managerial capacity to mitigate macroeconomic and social risks, are also identified.
\end{abstract}

Keywords: Economic growth, macroeconomic stability, post-WTO accession, economic recession.

\section{Introduction}

After eleven years of negotiation for accession, Vietnam eventually got the nod from the World Trade Organization (WTO) in November 2006. The country then became the 150th member of the WTO, with commitments being implemented since January 2007. At the time, optimism has been rising over the growth and development prospects of the country made available by, among others, the expansions in trade and investment inducement, and pressures to undertake further domestic reforms.
The past couple of years marked a memorable experience for Vietnam. After a long period of continuous high growth and macroeconomic stability, the country has appealed to foreign investors as one of the most attractive investment destinations. Achievements in foreign relations, along with such economic successes, have further consolidated Vietnam's position in the international arena. However, after a short period of over-excitement in the first half of 2007, Vietnam then had to start worrying about the overall economic situation. The accumulated 
inflationary pressures from continuous credit and public investment expansions, in combination with the external shocks such as rising energy and rice prices and inappropriateness of the policy responses to a surge in capital inflows in 2007 , sent the country to macroeconomic turbulence and the perplexity in formulating a proper stabilization policy. A policy package for dealing with macroeconomic instability has been implemented since March 2008. As the macroeconomic situation somehow improved by the end of 2008 , the country has suffered from very negative impacts of global financial crisis and recession.

In such a circumstance, assessing the impacts of the WTO accession on Vietnam's economy, in all aspects from economic ones such as trade, investment, growth, macroeconomic stability to more social ones and institutions, is no easy task. Proper analysis requires rigorous quantitative approach, at least to separate the impacts of the WTO accession and relevant shocks on each aspect of the economy under consideration, which goes beyond the scope of this paper. The paper, hence, restricts its focus to the conclusions from relevant studies, in comparison with the actual reality and statistics. It discusses, to a larger extent, the lessons that Vietnam can learn from the experience in the past two years of economic management, particularly with respect to the WTO accession as a key change factor.

The rest of the paper is structured as follows. Section II presents the analytical framework for examining the impact of the WTO accession on Vietnam's economy, and major empirical results anticipated prior to the accession itself. This provides the line for discussion of actual reality we could observe over the two years 2007-2008 in section III. The discussion is on real economy, macroeconomic and financial stability, social aspects, as well as economic institutions of the country. Section IV subsequently summarizes the main lessons for Vietnam as the first two-year period of WTO membership eventuates. Section V finally draws out some concluding remarks with respect to Vietnam's experience of changes in integration, including the WTO accession, and policy directions in the coming years.

\section{Analyses of the Impact of WTO Accession on Vietnam's Economy}

Figure 1 depicts a framework for analysing effects of external and policy factors on Vietnam's economy after its WTO accession. The WTO accession is often considered as a determinant of change in the economy. The channels of effect of the WTO accession are diverse, ranging from direct effects such as expansion in market access and foreign direct investment (FDI), to more indirect ones such as competition and pressures to further reform. Meanwhile, there are also interactions between commitments under the WTO framework and those under other trade arrangements (for example, AFTA, ASEAN-China FTA) to which Vietnam is a signatory. As the country is engaging more deeply into the regional and world economies, it may be more vulnerable to the economic turbulences taking place at regional or global level. Like other economies, Vietnam has been affected significantly by the oil and rice price shocks, and global financial crisis which has intensified since September 2008.

Especially, Vietnam's own policies in response to those changes, as well as those serving the country's long-term socio-economic development goals, are also to affect its economy in a number of ways. For many years, the policy focus was on high economic growth based on the investment, especially public investment and credit, expansion. The macroeconomic stability, to some extent, was neglected. Inflation emerged in 2004 and accelerated in the second half of 2007. But the turning point in terms of policy came only in March 2008. For the first time, the Government accepted the growth-inflation trade-off and attempted to implement a comprehensive policy package (including tightening monetary and fiscal policies as well as investments by State Business Groups) for fighting against inflation and stabilizing macroeconomy. Since October 2008, as the economy is facing the risk of economic downturn on global financial crisis, the Government has shifted the policies from stabilization to stimulation of the economic activities. The monetary policy has been eased and 
FIGURE 1

Analytical Framework of Impacts of WTO Accession on Vietnam's Economy

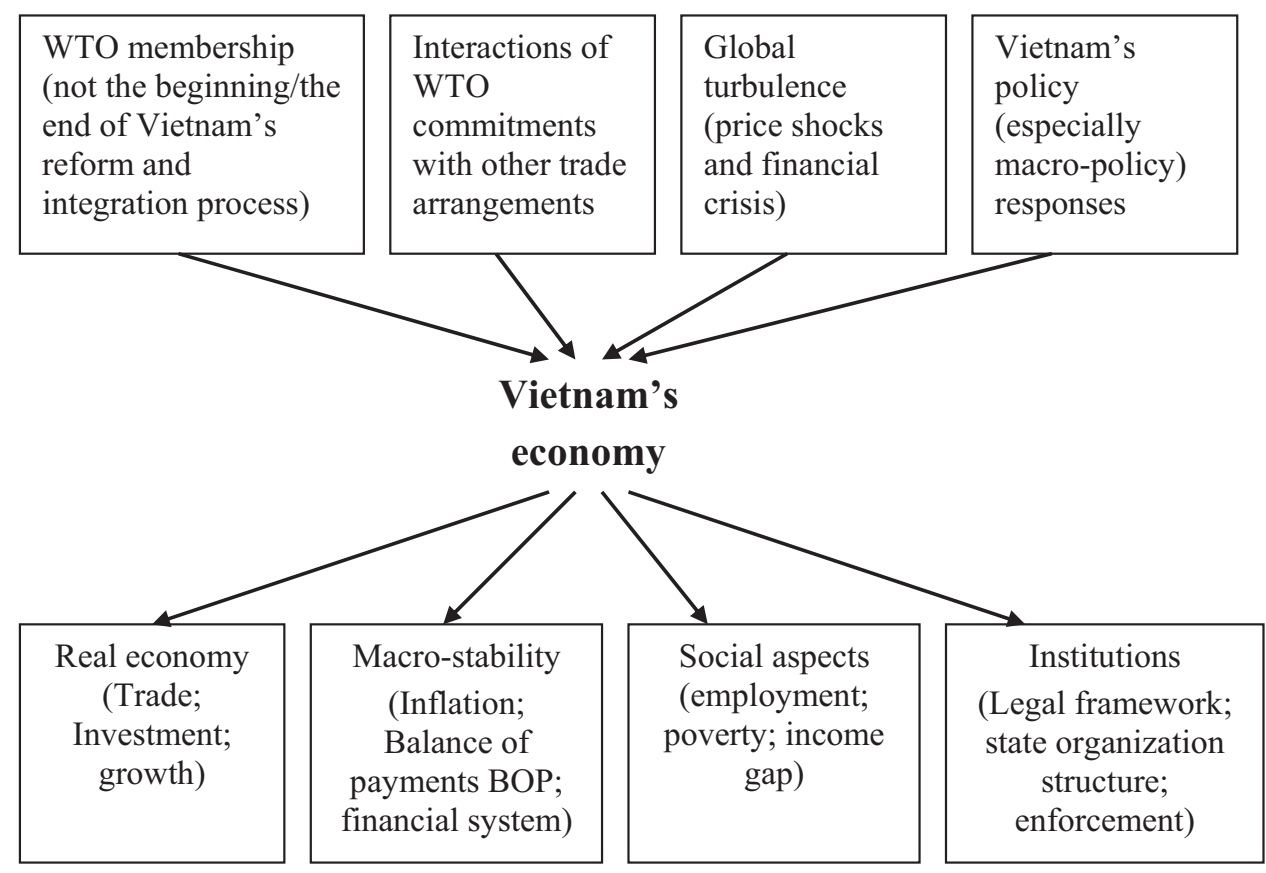

SOURCE: Authors' compilations.

a stimulus package of US\$6 billion ${ }^{1}$ for supporting infrastructure development, exports, small- and medium-sized enterprises (SMEs), and lowincome groups has been implemented.

On the other hand, there have been a number of empirical and case studies of the WTO accession and integration effects on Vietnam's economy. Studies mostly focus on changes in the real economy, including those in trade, investment, and growth performance. Various studies emphasize social effects, particularly with respect to employment and unemployment situations, poverty incidence, and income gap — at both national and interregional levels.

The studies at the aggregate level employ a computable general equilibrium (CGE) approach to look into the impacts on Vietnam's economy under different scenarios. Ideally, this approach allows for more systematic analyses of various sectors and aspects of the economy, and can be readily modified to capture the impacts on ones of main interest. Other analyses focusing on more sector-specific data, meanwhile, enjoy greater flexibility in their choices of analytic approaches. Examples of these techniques may include, but are not limited to, linear regressions and nonparametric analysis. Studies of this type mostly adopt a partial equilibrium analysis, and while this sheds more lights on a concerned aspect or sector of the economy, its net benefit from neglecting interactions in a more general equilibrium setting is not necessarily unambiguous.

Several key conclusions can be drawn from the empirical papers on impacts of WTO accession on Vietnam's economy. ${ }^{2}$ It is generally agreed that the gains for Vietnam from integration, in which WTO accession is one stepping stone, depend on a positive way on the extent and scope of its 
commitments in such a process. Specifically, making deeper and wider commitments appear to benefit Vietnam's economy much more. Such economic benefits, however, are conditional on various factors, including domestic reforms. Arguably, unless Vietnam undertakes domestic reforms in line with integration, most benefits would accrue to its trading partners. Furthermore, continuing unilateral liberalization is expected to bring about substantial benefits. That is, while the country can now enjoy part of the benefits from its implementation of WTO commitments over the past couple of years, it can further enhance the gains largely at its own will by reducing impediments to business in the domestic market.

At the aggregate level, the integration process in general and the WTO accession in particular have positive net impacts on Vietnam, especially on its real economy in various terms like export, investment, growth, and employment. These are largely driven by improved access to foreign market, competition pressures, technology transfer from and business linkages with foreign investment as well as pressures and/or incentives to institutional reforms and improvement of economic management. However, the WTO and integration are by no means risk-free. In fact, as Vietnam gets involved more deeply into the regional and the world economy and exploits its static comparative advantage in labour- and resource-intensive products with low value-added content, it faces greater risks of falling into "low cost labour trap" and lower position in the supply value chain in the long term.

Besides, imbalance between supply and demand of labours may worsen by region and skill. The concentration of economic activities in the regions with relatively more favourable conditions may cause significant gaps between supply and demand of labours across regions. Notwithstanding the induced interregional flows of labours, such gaps persist as a result of imperfect labour mobility. A number of new businesses and industries are also established in the integration process, leading to derived demand for labours of different skill levels. For many industries, particularly those with high technology, the supply of labour remains far too small relative to demand, while education and training of labour to meet the needs often come at significant costs, in terms of both time and money. A related problem is the widening of income gap. There is also a high possibility for some groups to fall back into poverty.

Being more deeply integrated into the regional and world economy, Vietnam gradually becomes more vulnerable to external shocks (e.g., price shocks). Mitigating the negative impacts of unfavourable developments in the world market turns out to be harder and/or more costly, even virtually impossible, given current market structures and/or policy constraints. Lack of experience in dealing with unfavourable shocks in a more liberalized market pose a challenge to Vietnam's policy-makers and businesses. Meanwhile, lessons from other countries are no more than a reference, as complicated by the different development level, market structure and more specific strengths/weaknesses of the country.

Trade deficit is also expected to grow significantly. Exports rely heavily on agricultural and raw commodities, while most manufacturing products still embody low value added. Imports of intermediate products and machinery, however, may keep rising relatively more rapidly, while overseas final products, particularly luxury ones, are imported with high value altogether as they appeal to Vietnam's consumers. In the longer term, budget revenue would improve while revenues from trade (imports) do not decline significantly. While tariff rates are expected to fall following Vietnam's commitments, the result is still consistent as import values go up and the base for calculating revenues from trade is thus larger.

All empirical studies of the possible impacts on Vietnam's economy following its WTO accession, however, share a couple of major drawbacks. Firstly, all studies seem to significantly underestimate the pace of growth of the country's exports and GDP. It seems that their quantitative analyses fail to properly account for a number of factors, the most notable of which are perhaps external shocks and institutional changes. ${ }^{3}$ Secondly, none of the studies have so far incorporated a rigorous analysis of, or even paid 
attention to, the inflows of foreign capital and macroeconomic issues associated with these. The channels of effects of capital inflows are often quantified in too simple a manner, if any, while such inflows in fact turn out to leave policymakers perplexed in a number of issues, for example, maintaining macroeconomic stability in the context of rapid capital inflows and its tradeoff in terms of economic growth. These are a few aspects that studies should address and overcome, if they are to bring more relevant information inputs to the policies dealing with WTO membership as a factor of change.

\section{Vietnam's Economic Development in 2007-20084}

\section{III.1 Real Economy}

Trade: Vietnam's comparative advantages seem to continue revealing through the export acceleration. The value of merchandize exports in
2007 and 2008 reached US $\$ 48.6$ billion and US $\$ 62.9$ billion or increased by 21.9 per cent and 29.5 per cent respectively. The export growth was mainly due to factors other than the enhanced market access under WTO framework. An export growth rate of 21.9 per cent in 2007 is neither impressive relative to that of 2006 (22.7 per cent) nor comparable to expectation prior to the country's WTO accession. The export growth rate of 29.5 per cent in 2008 resulted largely from a surge in world commodity prices. Excluding the effect of rising prices of major products such as rice, crude oil, coal, coffee, rubber, etc. (Figure 2), the total value of merchandise exports in 2008 only grew by less than 14 per cent. Moreover, monthly export fell significantly in the fourth quarter of 2008 due to the impact of global financial crisis which started to lead to a substantial reduction of commodity and oil prices as well as aggregate demand. In fact, the export growth rate in the first three quarters of 2008 was about 39 per cent.

FIGURE 2

Export Growth of Major Commodities/Products

(In percentages 2006-08)

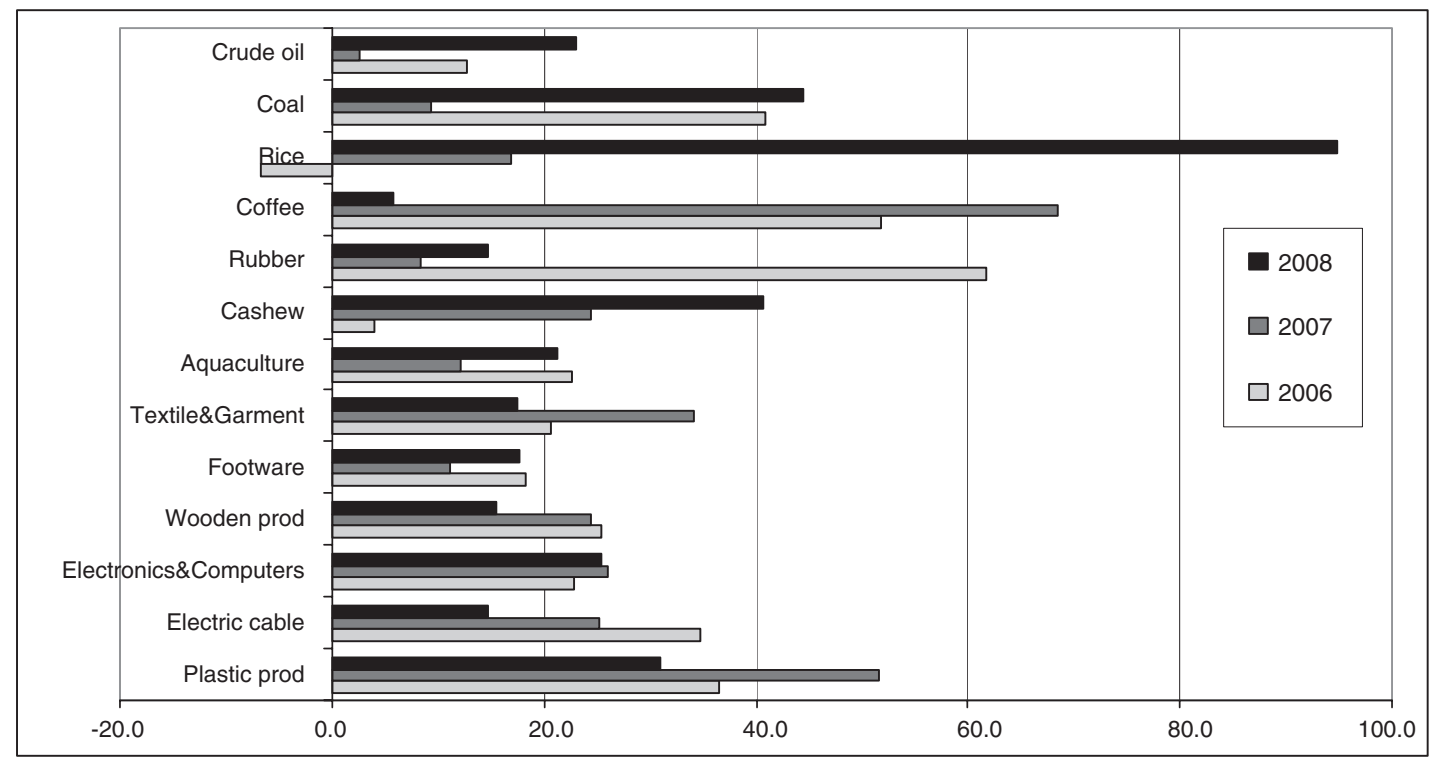

Source: General Statistics Office (GSO) and authors' calculations. 
The impact of the WTO accession on Vietnam's merchandise import appears to have been more clear-cut. The total value of merchandise import in 2007 reached US $\$ 62.7$ billion (measured at CIF prices) or grew by 39.6 per cent, representing a big jump from that of 20.1 per cent in 2006. This unambiguous significant impact was anticipated, yet still underestimated, prior to Vietnam's accession to the WTO. ASEAN member countries and China continue to be the main sources of Vietnam's imports. ${ }^{5}$ Notably, consumer goods were making up a greater proportion in total merchandise imports, of 11.4 per cent in 2007 compared to an average level of only 7.5 per cent in the years 1996-2006 (CIEM 2008b). This resulted from a combination of factors, including the increase in overall income as well as in assetgenerating income (wealth effect), and the reduction in import tariff. Even though such a proportion is not too large in absolute terms, attention should be given to its upward trend. In 2008 the total value of merchandise import was about US $\$ 80.4$ billion, but its growth decelerated to 28.3 per cent. This was the outcome of economic slowdown and the measures for restricting trade deficit appeared too large in 2007.

Investment: Vietnam's total investment is expected to rise in terms of overall GDP. The investment ratio, measured by total investment over GDP, was about 30 per cent in 2000 . The ratio increased to 38.9 per cent in 2005, 42.3 per cent in 2006 and 45.6 per cent in 2007 . It then decreased to 41.7 per cent in 2008 due to several reasons related to the tightening of state investments and stricter domestic credits. A salient feature of investment in Vietnam is that the state investment accounts for a large share of total investment although tending to go down continuously from 46.8 per cent in 2005 to 43 per cent in 2007 and 41.3 per cent in 2008 (Table 1).

During 2006-2007, the increase in real total investment was partly explained by the expansion of investment by the state-owned enterprises (SOEs), especially in 2006, and investment from budget. This trend somehow stopped in 2008 thanks to the Government's measures to tighten fiscal policy. The boom of private investment can be observed only till 2006. The share of private investment decreased continuously from 37.3 per cent in 2006 to 28.9 per cent in 2008 (Table 1). A rise in the state investment from budget appears to have crowding out effect on private investment.

But during 2006-2008, the key factor driving the change in Vietnam's total real investment was the massive surge in FDI inflows. Even in the context featured by the unfavourable development in and outside the economy in 2008, Vietnam continued to be a promising destination for FDI, reflecting foreign investors' confidence in its growth prospect. In 2007, registered FDI amounted to US $\$ 21.3$ billion, while implemented and disbursed FDI (through BOP) reached US\$8.1 billion and US\$6.7 billion, respectively. In spite of their being impressive, these figures appear to be far too small relative to that in the subsequent year. In 2008, an estimate of US\$64 billion of FDI was registered, and implemented and disbursed FDI already amounted to US\$11.5 billion and about US $\$ 8.3$ billion, respectively (Figure 3 and Table 3). Consequently, the share of FDI rose drastically from 15.9 per cent in 2006 to 24.8 per cent in 2007 and 29.7 per cent in 2008 (Table 1).

There are, however, some concerns of effectiveness of the recent FDI inflows. The ratio of implemented FDI over registered FDI was only 41per cent in 2006, 31 per cent in 2007 and 18 per cent in 2008 and much lower than the average during the 1988-2007 period (52.7 per cent). This was partially caused by the fact that some FDI projects were just registered for the purpose of "booking a place" in Vietnam. In fact, the ratio between chartered capital and registered capital was only 25.6 per cent in 2008 and much lower than that in the previous years. The slower FDI implementation was also due to the "bottlenecks" in Vietnam economy reflecting the weaknesses in institutions (despite improvement), infrastructure and human resources. Moreover, the negative impact of the global financial crisis became apparent in the fourth quarter of 2008. The pace of new FDI registration was significantly slower and the implementation of several FDI projects, particularly large ones, was delayed. 
TABLE 1

Investment Structure by Ownership

(Current Price; 2006-08)

\begin{tabular}{lrrr}
\hline & 2006 & 2007 & 2008 \\
\hline Total investment & & & \\
$\quad \%$ GDP & 42.3 & 45.6 & 41.7 \\
$\quad$ Increase (\%) & 26.5 & 26.5 & 19.2 \\
Inflation (\%) & 6.6 & 12.6 & 19.9 \\
State investment & & & \\
$\quad$ Share of total investment (\%) & 46.8 & 43.0 & 41.3 \\
$\quad$ Increase (\%) & 16.6 & 16.2 & 14.7 \\
In which: - State budget & & & \\
$\quad$ Share of total investment (\%) & 23.4 & 24.7 & 24.4 \\
$\quad$ Increase (\%) & 12.0 & 34.0 & 17.8 \\
$\quad$ State credits & & & \\
$\quad$ Share of total investment (\%) & 8.5 & 6.7 & 6.4 \\
$\quad$ Increase (\%) & 16.3 & 0.6 & 14.0 \\
$\quad$ SOEs & & & \\
$\quad$ Share of total investment (\%) & 14.9 & 11.5 & 10.5 \\
$\quad$ Increase (\%) & 24.7 & -2.6 & 8.3 \\
Non-state investment & & & \\
$\quad$ Share of total investment (\%) & 37.3 & 32.3 & 28.9 \\
$\quad$ Increase (\%) & 43.1 & 9.3 & 7.0 \\
FDI investment & & & \\
$\quad$ Share of total investment (\%) & 15.9 & 24.8 & 29.7 \\
$\quad$ Increase (\%) & 23.8 & 97.1 & 43.1 \\
\hline
\end{tabular}

NoTE: Investment from budget includes other mobilized funds.

Source: Ministry of Planning and Investment (MPI) and authors' calculations.

Economic Growth: Supported by the achievements in exports and investment, Vietnam's economy continued to grow rapidly after its WTO accession. In 2007, GDP growth remained high at 8.5 per cent, compared to that of 8.2 per cent in 2006 (Table 2), though the sustainability of such a high growth was, at the time, still questionable due to concerns of low public investment efficiency. The year 2008, however, witnessed the fear of macroeconomic instability and global financial crisis and recession, which caused economic activities and growth to slow down. The economic growth rate was only 6.2 per cent (while that for the first 9 months attained 6.5 per cent).
From the supply side, GDP growth continued to be driven by the industry-construction activities. However, the sector experienced a decline in its share from around 41.6 per cent in 2006 to roughly 39.9 per cent in 2008. Notably, the share of manufacturing appears to change in line with that of the overall industry-construction sector, whilst that of construction sector declined significantly in 2008 with the growth rate of nearly 0 per cent. Meanwhile, the share of agriculture-forestry-aquaculture in GDP has increased from 20.4 per cent in 2006 to 22 per cent in 2008, though quite a number of supply shocks to the sector were in place. The years 
FIGURE 3

FDI in Vietnam, 1988-2008

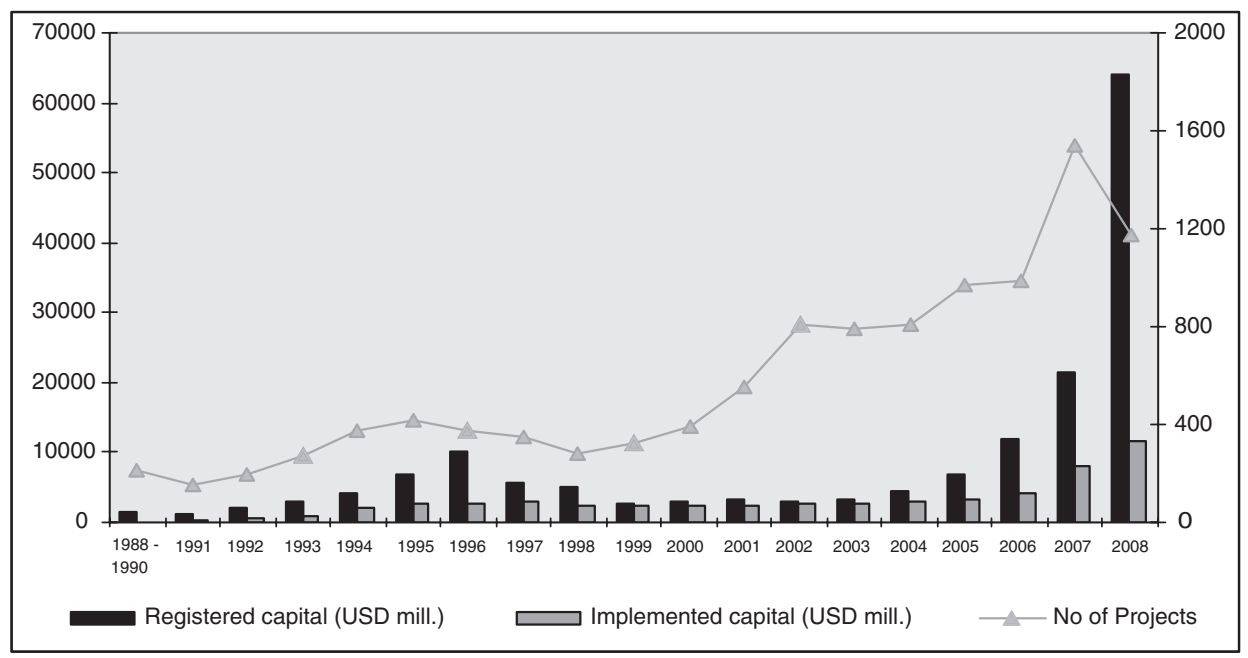

NotE: Registered capital includes that of both newly registered and expanded existing projects. SOURCE: MPI.

TABLE 2

Main indicators of Vietnam's Real Economy, 2006-2008

\begin{tabular}{lcrrr}
\hline & Unit & 2006 & 2007 & 2008 \\
\hline GDP growth & $\%$ & 8.2 & 8.5 & 6.2 \\
Share in GDP (Current prices) & $\%$ & 100.0 & 100.0 & 100.0 \\
\multicolumn{1}{c}{ Agriculture-Forestry-Aquaculture } & $\%$ & 20.4 & 20.3 & 22.0 \\
\multicolumn{1}{l}{ Industry-Construction } & $\%$ & 41.6 & 41.6 & 39.9 \\
— Manufacturing & $\%$ & 21.3 & 21.4 & 21.2 \\
Services & $\%$ & 38.0 & 38.1 & 38.1 \\
Registered FDI & US\$ mill. & 12,004 & 21,300 & 64,000 \\
Implemented FDI & US\$ mill. & 3,956 & 8,050 & 11,500 \\
Merchandise export (fob) & US\$ mill. & 39,826 & 48,561 & 62,900 \\
- Growth & $\%$ & 22.7 & 21.9 & 29.5 \\
Merchandise import (cif) & US\$ mill. & 44,891 & 62,680 & 80,400 \\
- Growth & $\%$ & 20.1 & 39.6 & 28.3 \\
Trade/GDP & $\%$ & 137.5 & 156.0 & 161.0 \\
\hline
\end{tabular}

SouRCE: Data provided by MPI and GSO and authors' estimations. 
2006-2008 witnessed a boom of some services sub-sectors such as financial and retailing sectors but have not yet made a significant contribution to real economic growth. The overall share of services sector reached around 38 per cent GDP during 2006-2008. ${ }^{6}$

From another perspective, Vietnam's economic growth relies heavily on foreign savings. Due to the rapid increase in domestic consumption during 2007-08, domestic savings as a proportion of GDP experienced continuous falls from 30.6 per cent in 2006 to 29.1 per cent of GDP in 2007 and 28.8 per cent in 2008. As domestic investment expanded, the domestic savings-investment gap (much more than 10 percentage points) kept widening, and it would be hard to be met by overseas capital in sustainable manner.

\section{III.2 Macroeconomic and Financial Stability}

Inflation: As depicted in Figure 3, the CPI-based inflation on a year-on-year basis though not low but had been rather stable till the third quarter of 2007. From September 2007 onwards, however, the pace of growth in consumer prices accelerated.
By the end of 2007, year-on-year inflation already reached 12.6 per cent (Figure 4). The figure subsequently rose drastically to 28.3 per cent in August 2008 and even maintained a high rate of 16.5 per cent after removing the prices of food and foodstuff which are highly weighted in the basket of goods and services for calculating CPI (about 43 per cent). The administrative upward adjustment of petroleum price had also some effect on higher inflation (note that the Government decided to raise petroleum price by 31 per cent to reduce subsidy bills in July 2008 and to allow it to move largely following international price since August 2008). Since September 2008, the month-on-month inflation has declined significantly, to -0.19 per cent October, -0.76 per cent in November and -0.68 per cent in December, leaving the year-on-year inflation rate of 19.9 per cent for the whole 2008 . The reason behind the fall was both "good luck" (falling international prices of rice and fuels) and "better policy implementation" (the impact of stabilization policies).

Several causes of the rapid surge in inflation have been identified. Firstly, expansionary

FIGURE 4

Year-on-Year CPI-based Inflation (January 2006 - December 2008)

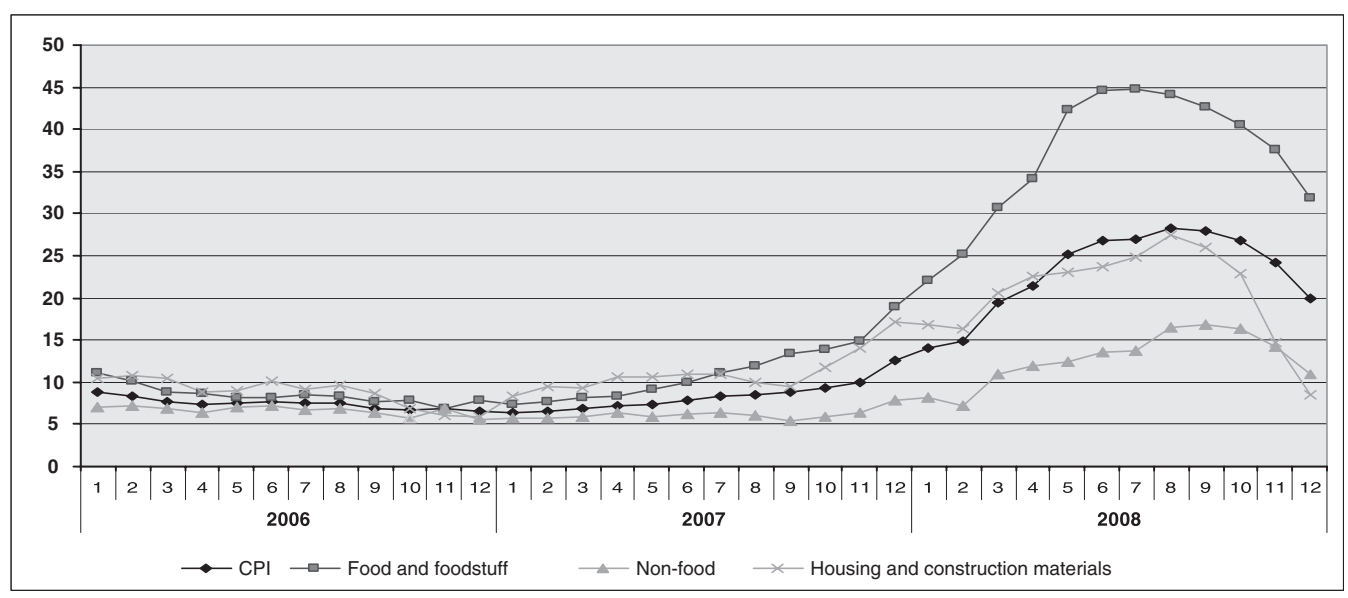

SOURCE: GSO and authors' compilations. 
macroeconomic policies for many years, whilst facilitating continuous rapid growth over the past period, have also contributed to building up dramatic pressures on inflation. This problem was further magnified by the increase in international prices and complicated trade-offs in domestic price stabilization policy. Secondly, the massive unprecedented increase in foreign capital inflows in 2007 left policy-makers with enormous perplexity, particularly in formulating policy response. The attempt to control money supply in the second half of 2007 was ineffective (and costly). As a result, money supply, whether in terms of M2 or domestic credit, in 2007 increased by more than 50 per cent. Some other measures to tighten monetary policy were implemented in the early of 2008. But the fiscal policy, to a considerable extent, was still passive in coordination to monetary policy. According to Vo and Pham (2008), "the macroeconomic policy responses up to the February 2008 seem to be less effective in stabilizing the economy and in reducing policy inconsistencies as well as financial risks".
Balance of Payments (BOP): Vietnam ran a huge current account deficit, valued at nearly US\$7 billion or almost 9.9 per cent of GDP in 2007 and US $\$ 12.3$ billion or 13.6 per cent GDP in 2008 . This result is remarkable, given the fact that the country only incurred a current account deficit of US $\$ 0.2$ billion or 0.3 per cent of GDP in 2006 . The increase in current account deficit was largely due to the surge in trade deficit of nearly US $\$ 10.4$ billion (14.6 per cent of GDP) in 2007 and US $\$ 14.4$ billion (15.9 per cent of GDP) in 2008, from nearly US\$2.8 billion (or 4.6 per cent of GDP) in 2006. However, in 2007 the overall balance of payments was in a massive surplus, reaching US\$10.2 billion, which led to a significant increase in foreign reserves. The major cause of such a surplus was large inflows of remittance, FDI, ODA, and portfolio investment. The capital account situation changed dramatically but the overall BOP was in surplus of only US $\$ 0.5$ billion (Table 3$)^{7}$

The rapid increases in inflation and trade deficit, especially in the first half of 2008, have combined to exert high pressures on dong to

TABLE 3

Vietnam's Balance of Payments, 2006-2008

\begin{tabular}{|c|c|c|c|c|c|c|}
\hline & \multicolumn{2}{|c|}{2006} & \multicolumn{2}{|c|}{2007} & \multicolumn{2}{|c|}{$\begin{array}{c}2008 \\
\text { (projection in Sep }\end{array}$} \\
\hline & $\$ m$ & $\% G D P$ & $\$ m$ & $\% G D P$ & $\$ m$ & $\% G D P$ \\
\hline Current Account & -164 & -0.27 & $-6,992$ & -9.85 & $-12,288$ & -13.6 \\
\hline Trade balance (fob) & $-2,776$ & -4.55 & $-10,380$ & -14.59 & $-14,422$ & -15.9 \\
\hline Services & -8 & -0.01 & -894 & -1.26 & $-1,725$ & -1.91 \\
\hline Investment income (net) & $-1,429$ & -2.34 & $-2,168$ & -3.05 & $-2,340$ & -2.56 \\
\hline Transfer (net) & 4,049 & 6.64 & 6,430 & 9.06 & 6,220 & 6.86 \\
\hline - Private & 3,800 & 6.23 & 6,180 & 8.70 & 6,000 & 6.64 \\
\hline Capital Account & 3,088 & 5.06 & 18,771 & 2,644 & 13,396 & 14.82 \\
\hline FDI (net) & 2,315 & 3.80 & 6,600 & 9.30 & 8,100 & 8.96 \\
\hline Medium + Long-term Loan (net) & 1,025 & 1.68 & 2,043 & 2.88 & 928 & 1.03 \\
\hline Short-term loan & -30 & -0.05 & 91 & 0.13 & 2,768 & 3.06 \\
\hline Portfolio investment & 1,313 & 2.15 & 7,414 & 10.44 & 1,680 & 1.86 \\
\hline Currencies and deposits & $-1,535$ & -2.52 & 2,623 & 3.69 & & \\
\hline Overall balance (adjusted for errors) & 4,322 & 7.09 & 10,168 & 14.32 & 496 & 0.55 \\
\hline
\end{tabular}

SOURCE: Author's compilations. 
depreciate. However, since August 2008, the stabilization policy package that Vietnam implemented began to take effect. As a result, trade deficit situation seemed to be improved, and together with lower inflation, this in turn helped ease the pressure of dong devaluation.

Moreover, Vietnam's current accumulated foreign debt remains below 30 per cent of GDP, while the ratio of debt services is no more than 4 per cent. The structure of foreign debts, however, exhibited a remarkable change. Prior to 2008, foreign debt comprised mostly of mediumand long-term loans, while the share of short-term ones was small. Although this trend continued in the first half of 2008, a significant amount of short-term loans of nearly US $\$ 2.8$ billion would be estimated for the whole 2008 (Table 3). In another aspect, Vietnam's international reserves rose dramatically from US $\$ 11.5$ billion in 2006 to US $\$ 20.7$ billion in June 2008 and about US\$23 billion in October 2008.

At present, there is, however, uncertainty of pressures on the exchange rate movement. This is very much associated with the expectation of inflation, trade deficit, and the difficulties in mobilizing foreign capital in a context of serious "dollarization" and "goldization" in Vietnam and the ease of Vietnam's macroeconomic policies for stimulating the economic activities.

Financial System: The years 2006 and 2007 witnessed a boom of activities in banking industry as well as in the capital and real estate markets. Such a boom resulted from the expectations of profit opportunities once Vietnam opened its services market in line with WTO commitments. Despite the dominance of state-owned commercial banks (SOCBs) in the banking system, the role of joint-stock commercial banks (JSCBs) has been on the increase, as reflected by the shares of this latter group in total deposits and total credits of 30.4 per cent and 28.6 per cent, respectively, in $2007 .^{8}$ The banks kept expanding their branches and subsidiaries, and the pace of expansions has been enormous over the past couple of years. The depth of the financial system, as measured by, for example, the ratios of M2/GDP and total credit/
GDP, has improved significantly. While the ratio of total credit over GDP went up from 74.4 per cent in 2004 to 82.5 per cent in 2007 , the M2/ GDP ratio almost doubled from 58.7 per cent to 112.1 per cent over the same period (CIEM 2008b).

However, the boom in banking and financial activities has also posed greater risks to the financial system. This increase in risks is partly due to the lack of adequate fundamentals for sustainable financial development in the longer term. Firstly, the capacity to manage and control risks remained weak, and failed to catch up with the boom in financial and banking industry. Such a weak capacity at the micro level constrained the efficiency and prudential management as banking - financial institutions expand the scale and scope of their investment activities. Meanwhile, the monitoring and surveillance system at the macro level lags far behind the development of the market, while macroeconomic indicators are currently worrisome.

Secondly, the banking system appeared to suffer from a lack of liquidity, particularly in the first half of 2008. The declining propensity to save of the households left the banks and other depository institutions in fierce competition to attract deposits. Simultaneously, measures by the State Bank of Vietnam to control credits, including some administrative ones to withdraw money from circulation, caused the banks, particularly small JSCBs, to be in a stranded situation, with insufficient funds to meet their lending and investment needs. The situation, nonetheless, has eased significantly since July 2008.

Thirdly, some banks also experienced serious maturity mismatch. The ratio of long-term loans in total credit seemed to be too high. At the same time, due to uncertainty in the overall macroeconomic situation, the households were more inclined to make short-term deposits. This problem was further complicated by the increase in non-performing loans, particularly those made for purposes of consumption and real estate investment, etc., in the second half of 2008.

Till the end of 2005, the securities market in Vietnam had still been of small scale. From June 
2006 to 2007, however, the market went for rapid expansions in terms of capitalization, number of listed companies, participation of domestic and foreign investors. Together with the boom of the securities market, the number of securities companies and investment funds also skyrocketed. The years 2006 and 2007 also witnessed a rapid surge in foreign indirect investment flows into Vietnam's securities market. Such developments in the securities market result from various factors, including the continuous rapid growth of Vietnam's economy, improvement in business and investment environment due to the WTO accession and associated reforms. More recently, due to fears of macroeconomic stability as well as the contagion effect of the financial crisis, the securities market has been on the decline, as reflected by the relatively unambiguous downward trend in the VN-index, falling from around 1,100 in October 2007 to about 300 in late December 2008 (Figure 5).
State Budget: Total budget revenue kept going up in absolute terms. As can be seen from Table 4, the total revenue increased continuously from just below 280 trillion dong in 2006 to almost 400 trillion dong in 2008. Such an increase was driven mainly by the rises in domestic revenue as well as revenue from trade activities. Domestic revenue tended to change in line with the trend of overall economic activities. Notably, despite Vietnam's tariff cuts following the WTO accession since 2007, trade revenues still climbed, from less than 43 trillion dong in 2006 to over 60 trillion dong in 2007 and around 83 trillion dong in 2008. This was consistent with the previous discussion that the base for calculating tariff revenue became larger following the tariff cuts. That is, tariff revenues increased substantially due to import expansion. Despite increasing in absolute terms, total budget revenue has been declining relative to GDP. The ratio of total budget revenue over GDP went down continuously from 28.7 per cent in

FIGURE 5

VN Index, January 2005 - December 2008

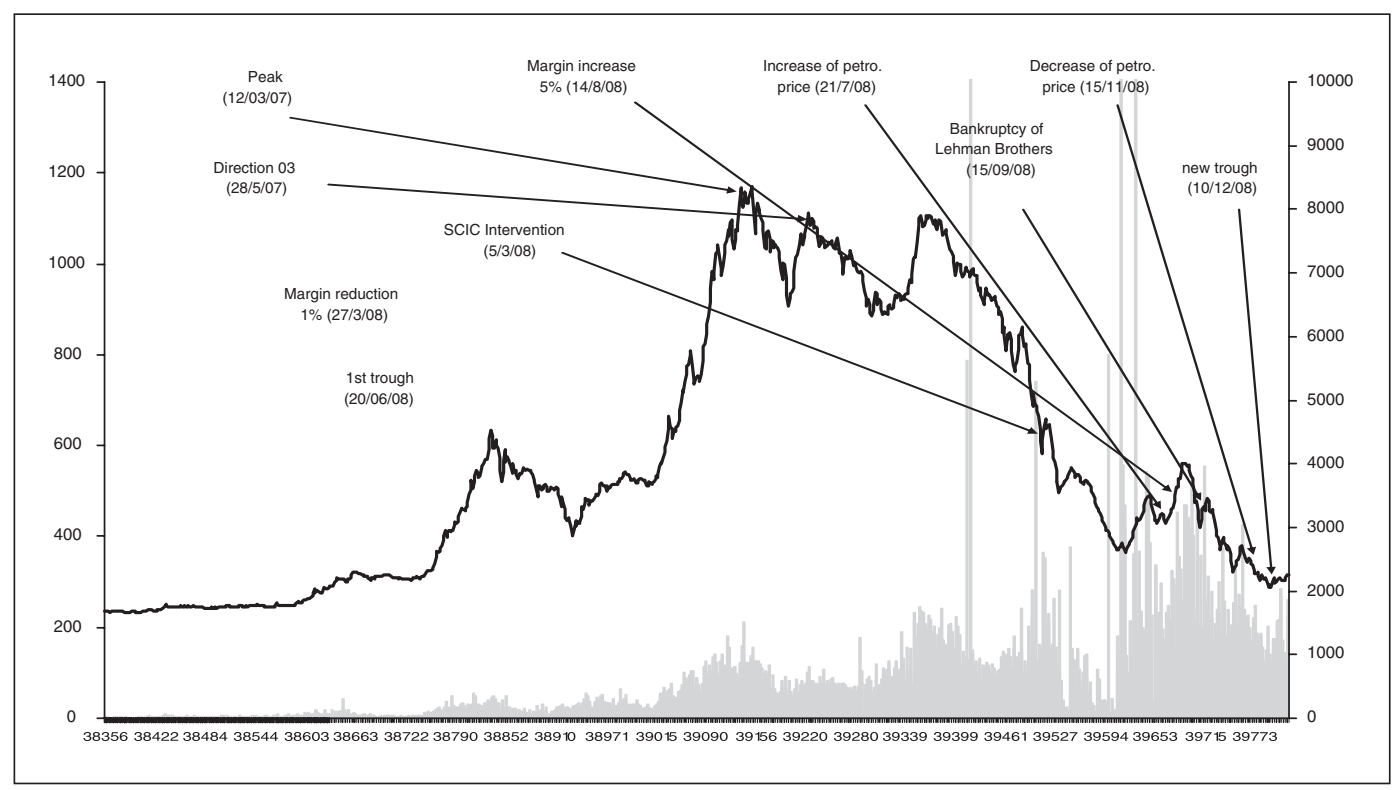

SOURCE: Author's compilations. 
2006 to 27.6 per cent in 2007 , and 26.8 per cent in 2008. Relying too heavily on trade revenues as well as those from crude oil, with high volatility, total budget revenue will continue to exhibit considerable uncertainty.

Fiscal policy was not significantly tightened in 2008. The ratio of budget deficit over GDP remained rather stable at 5 per cent in 2006 and 2007, before declining slightly to 4.95 per cent in 2008. Apart from the contract in tariff revenues, and economic activities induced by the global financial crisis and recession, Vietnam's fiscal stimulus via tax cuts and expenditure expansion are likely to add further pressures on the budget deficit, especially in the short-term.

\section{III.3 Social Issues}

The integration process generally has positive impacts on job creation, via development of labour-intensive industries. According to the Enterprise Surveys in 2001 and 2007, the number of jobs in manufacturing sector rose considerably, by more than 110 per cent to 3.4 million, due to enormous newly founded enterprises. Along with the shift in economic structure by sector, labours tend to move away from agriculture-forestryfishery to industry and services. The labour share of agriculture-forestry-fishery went down from 54.7 per cent in 2006 to 52.2 per cent in 2007 , while those of industry-construction, and of services increased from 18.3 per cent to 19.2 per cent and from 26.9 per cent to 28.6 per cent, respectively.

Relative to the situation prior to the WTO accession, job creation in 2007 is insufficiently impressive. The working labour force increased by 2.3 per cent, compared to 2.7 per cent in 2006. In urban areas, the unemployment rate initially decreased slightly from 4.8 per cent in 2006 to 4.6 per cent in 2007, before rising rapidly to around 5.1 per cent in 2008. Furthermore, the unemployment rate of young people increased; 42.5 per cent of unemployed persons were of between 15 and 24 years of age, and this group suffered from the highest unemployment rate of roughly 14.2 per cent (CIEM 2008b).

Higher vulnerability to external shocks also poses greater challenges to social life of Vietnam's people, most of whom are having medium or low income with little diversity in income sources. The effect of high inflation over the past couple of years is a convincing example. Such a dramatic surge in overall consumer price level, which was well in excess of wage increase, seriously undermined the real income of various social groups. As illustrated in Table 5, real income was generally improved for employee of all enterprises in 2006 and in 2007, whilst being severely hit by high inflation in 2008. Even the effect is uneven across different labour groups. In fact, income of employees in high value-added services sectors

TABLE 4

State Budget Revenues, 2006-2008

\begin{tabular}{|c|c|c|c|c|c|c|}
\hline & \multicolumn{2}{|c|}{2006} & \multicolumn{2}{|c|}{2007} & \multicolumn{2}{|c|}{2008} \\
\hline & $\begin{array}{c}\text { billion } \\
\text { dong }\end{array}$ & $\begin{array}{c}\% \text { of Total } \\
\text { Revenue }\end{array}$ & $\begin{array}{c}\text { billion } \\
\text { dong }\end{array}$ & $\begin{array}{c}\% \text { of Total } \\
\text { Revenue }\end{array}$ & $\begin{array}{c}\text { billion } \\
\text { dong }\end{array}$ & $\begin{array}{c}\% \text { of Total } \\
\text { Revenue }\end{array}$ \\
\hline Total State Budget Revenue & 279,500 & 100.0 & 315,900 & 100.0 & 399,000 & 100.0 \\
\hline Domestic Revenue & 145,400 & 52.0 & 174,300 & 55.2 & 205,000 & 51.4 \\
\hline Revenue from crude oil & 83,300 & 29.8 & 77,000 & 24.4 & 106,000 & 26.6 \\
\hline Import-Export & 42,800 & 15.3 & 60,400 & 19.1 & 83,000 & 20.8 \\
\hline
\end{tabular}

SOURCE: Ministry of Finance and authors' compilations. 
increased much faster than that in labour-intensive manufacturing industries (facing tough competition). As such, the social effect of inflation on the former group of labours might not be as severe as that on the latter one. Besides, slower growth in 2008 , especially in the fourth quarter of 2008 , led to sizeable job losses and associated reduction in income.

In another aspect, household poverty incidence shrank from 15.5 per cent in 2006 to 14.7 per cent in 2007 and 13.1 per cent in 2008. The direct effect of the WTO accession on poor households is arguably not large as these households are unlikely to be involved substantially in export and/or high-technology industries (CIEM 2008b). Alternatively, indirect effects via provision of individual and community services, as well as food and foodstuff, to income-improving households may be more significant. Several factors, however, still require further research. The impact of higher food prices on farmers is ambiguous, depending on whether they are net sellers or buyers. Besides, the poverty line in 2005 is no longer valid, due to dramatic changes in inflation and, accordingly, the purchasing power of money in Vietnam. Taking into account the purchasing power parity, actual poverty rate should be around 15-16 per cent by the end of
2008. Failure to adjust for this will lead to inaccurate assessment of social instability risk, and lower effectiveness of social supports.

It is also important to examine the question of households' gains from the increase in rice price in 2008. Not all households engaged in rice production benefit from that fact. This depends on whether they are net sellers or buyers of rice. Table 6 indicates that about 43.8 per cent of Vietnam's households (out of 52.5 per cent households engaged in production of rice), who are net rice sellers, could have a benefit. The proportion of the poor ( 60.2 per cent) benefited from the rice price increase is larger than that of the non-poor. But in general this kind of benefit in 2008 was small as increase in income from rice selling could be offset by the substantial rises in input costs and inflation.

Despite the lack of proper quantification, several anecdotal evidences on Vietnam's income gap can be brought forward. The poverty incidence remained high in the years 2007-08, while thousands of people scattering around the country still suffered from hunger. A certain group in big urban cities such as Hanoi and Ho Chi Minh City, on the contrary, can easily get access to luxury consumer goods, such as expensive cars and modern housings. As a positive development,

TABLE 5

Average Wage of an Enterprises' Employee (thousand dong, \%)

\begin{tabular}{|c|c|c|c|c|c|c|}
\hline & \multicolumn{2}{|c|}{2006} & \multicolumn{2}{|c|}{2007} & \multicolumn{2}{|c|}{$1^{\text {st }}$ half 2008} \\
\hline & $\begin{array}{l}\text { Ave. } \\
\text { wage }\end{array}$ & $\begin{array}{c}\% \\
\text { increase }\end{array}$ & $\begin{array}{l}\text { Ave. } \\
\text { wage }\end{array}$ & $\begin{array}{c}\% \\
\text { increase }\end{array}$ & $\begin{array}{l}\text { Ave. } \\
\text { wage }\end{array}$ & $\begin{array}{c}\% \\
\text { increase }\end{array}$ \\
\hline SOE & 2,633 & 23.0 & 3,050 & 15.8 & 3,530 & 15.7 \\
\hline Non-State & 1,488 & 14.2 & 1,660 & 11.6 & 1,860 & 12.0 \\
\hline FDI & 2,175 & 11.8 & 2,450 & 12.6 & 2,750 & 12.2 \\
\hline \multirow[t]{2}{*}{ Overall } & 1,969 & 15.0 & 2,235 & 13.5 & 2,525 & 13.0 \\
\hline & \multicolumn{2}{|c|}{$\begin{array}{c}\text { Wage increase }>> \\
\text { inflation }(6.3 \%)\end{array}$} & \multicolumn{2}{|c|}{$\begin{array}{l}\text { Wage increase > } \\
\text { inflation }(12.6)\end{array}$} & \multicolumn{2}{|c|}{$\begin{array}{l}\text { Wage increase }<< \\
\text { inflation }(18.4 \%)\end{array}$} \\
\hline
\end{tabular}

Source: Nguyen (2008). 
TABLE 6

Share of Households in Agricultural Sector and in Rice Production (2007)

\begin{tabular}{lccc}
\hline & $\begin{array}{c}\text { Agricultural } \\
\text { households (\%) }\end{array}$ & $\begin{array}{c}\text { Households engaged } \\
\text { in rice }\end{array}$ & $\begin{array}{c}\text { Net rice seller } \\
\text { households (\%) }\end{array}$ \\
\hline Whole country & 71.9 & 52.5 & 43.8 \\
Rural areas & 86.2 & 66.0 & 54.4 \\
Urban areas & 29.3 & 12.3 & 11.9 \\
Non-poor households & 68.5 & 48.1 & 40.7 \\
Poor households & 90.4 & 76.7 & 60.2 \\
\hline
\end{tabular}

SourCE: Nguyen (2008).

however, the middle class are emerging rapidly. In the future, people in this class are expected to exert greater influences on social behaviours, consumption patterns, and the policy making process as well.

\section{III.4 Impacts on Economic Institutions}

The interaction between Doi Moi (Renovation), domestic economic reforms, and integration/WTO accession has become increasingly apparent. In the years 2005-2006, Vietnam had made enormous institutional preparations to acquire WTO membership. These preparations included, but were not restricted to, approval of twenty-seven new laws, including the (common) Investment Law and the (unified) Enterprise Law which make the business playing field in Vietnam more level.

Subsequent to the National Party Congress in 2006 and the National Assembly election in 2007, the Government apparatus was somehow improved, with the number of ministries and ministerial-level agencies falling from twenty-six to twenty-two. The process of administrative reform and application of "one-stop-shop" mechanism continued to be implemented following a number of documents, including the Prime Minister Decision No. 30/2007/QD-TTg, in January 2007, on the Comprehensive Program on Simplification of Administrative Procedures in the years 2007-10, and the Prime Minister Decision No. 93/2007/QD-TTg, in June 2007, on the
Implementation of One-Stop-Shop Mechanism in Local Public Administrative Agencies. However, the Decisions on functions of various ministries progressed slowly, while the reorganization of provincial authorities (departments) was delayed until January 2008. As a result, the effectiveness of central and local authorities was negatively affected.

To grasp the opportunities and to overcome challenges from the WTO accession, notably, Vietnam has adopted a new way for WTO implementation. Following the Party Resolution No. 08-NQ/TW on Major Policy Guidelines for Rapid and Sustainable Economic Development after Vietnam becomes WTO Member, the Government approved the Resolution No. 16/ 2007/NQ-CP dated 27 February 2007 on its Action Plan. Pursuant to the Government Resolution, the Ministries and provincial People's Committees have to prepare their own action plans, and submit to the Central Government for approval. This process receives support from international donors, within the two-phase Beyond WTO Program, along with technical consultation with the independent High-Level Advisor Group.

The approach based on action plans has its own strengths and weaknesses. On the positive side, it allows for unambiguity in the direction for reform. Besides, comprehensiveness can be achieved in the implementation of WTO commitments, as the action plans can be readily modified to incorporate issues related to information dissemination, 
training; improvement of institutions (rule of games, administration); investment efficiency; human resource development; competitiveness; agriculture and rural development; social safety net; sustainable development, etc. What's more, the action plans prepared by ministries and local authorities will comply better with their functions, i.e. what they can do best by themselves and/or in collaboration with other ministries/authorities. In a related aspect, those action plans may take into better consideration of the advantages and disadvantages of localities, which are among the key determinants as to whether the plans are effective locally or not. As the provincial action plans endow the localities with more autonomy, they acquire greater freedom to implement new ideas for breakthrough development. That is, action-plan-based approach may allow for more effective competition among the provinces and give them greater incentives to pursue development within the WTO accession, rather than relying solely on the State's plan.

On the negative side, however, several weaknesses of the action-plan-based approach can be noticed. The submissions of all ministry/ provincial action plans were behind the schedule, while some provinces even fail to submit. The provinces tend to look at one another in preparing the work, and rely almost solely on technical support from advisor group. Several action plans, meanwhile, were too formal and specified hardly any specific measures to be practically feasible. Whilst attempting to prepare comprehensive action plans, ministries and provinces often fail to identify the tasks of higher priority and/or urgency. This is a critical drawback as grasping the opportunities and mitigating risks from the WTO accession are other than once-off tasks, nor will ministries and provinces have enough current resources to implement the action plans. Moreover, the prepared action plans handle poorly the cross-cutting issues which involve linkages by sector and by region. They also fail to incorporate the voice of the business community about their concerns and their needs. The tasks of monitoring, supervising and making necessary adjustment to action plans are addressed improperly (Beyond
WTO Design Team 2008; High Level Advisory Group 2008).

\section{Major Lessons}

The two years of 2007-08 witnessed the significant early impacts, both direct and indirect, of the WTO membership on Vietnam's economy. The actual changes in several variables/aspects, such as confidence in long-term development and reform; efficiency of resource allocation; export, investment, growth, and interaction between integration and domestic reforms, were basically as expected. Nevertheless, the scale/scope of changes in many variables is far more/less than predictions or could not be thought of. The factors such as international price or financial shocks, scale of foreign investment inflows, the expansion of financial and banking activities, etc., had failed to be properly accounted for. Several weaknesses and macroeconomic risks in the economy were hidden until 2007 by a relatively high economic growth. The problems were further complicated by the inappropriate (macro) policy responses and/or adjustments.

The hallmarks of the experience with Vietnam's socio-economic development over the first two years of WTO membership are memorable. Several major lessons can be drawn from Vietnam's experience.

Firstly, coordinating domestic reforms with international and WTO commitments and using these commitments as a "good pressure" for reform are critical to establish and/or consolidate the confidence/credibility of (local and foreign) investors and business community on Vietnam's development potential in the long run.

Along with the process, adjusting macroeconomic policy and strengthening financial monitoring and supervision are all necessary supporting measures. These should attract more attention, particularly as Vietnam is finding itself being more deeply involved in international economic integration.

Secondly, deeper and wider economic integration facilitate more efficient utilization of Vietnam's static comparative advantages. Induced 
by factors such as competition, economies of scale, and FDI inflows, the dynamic comparative advantages of the country also become more apparent.

While fully utilizing the traditional comparative advantages, a strategy for Vietnam's firms is to start moving up along the value chain by diversifying/differentiating export products and strengthening non-price competitiveness, attracting efficient FDI/strategic partners, and improving labor and management skills.

Thirdly, the WTO membership has further revealed the inherent weaknesses of Vietnam's economy, the resolutions of which require more comprehensive and determined reforms.

Economic growth fails to embody sufficient improvement in quality, as it is largely based on the expansion of investment, including inefficient public investments, while Vietnam's firms stand at the lowest position in value chain. The economic growth of 8.5 per cent in 2007 is not so impressive given the fact that these figures are 8.4 per cent in 2005 and 8.2 per cent in 2006. As another indication, the financial boom in 200607 had no corresponding impact on the creation of value added. The share of 2 per cent GDP accounted for by the financial sector was unchanged in last few years.

Besides, despite some improvements, the institutional capacity remains a key bottleneck for Vietnam's sustainable development. There still exists a huge gap between requirements (professionalism, transparency, accountability) and incentives system for the public machinery and administration to function properly. The coordination among agencies and ministries is still weak and insufficiently effective. The establishment of necessary institutions for developing production factor markets is far from completion. Although the financial activities are flourishing, supervision of the financial system remains inadequate.

Another bottleneck in Vietnam is the low quality of its human resource, albeit having high literacy rate. The gaps between demand and supply of labours by sector and by skill are sizeable, while policy-makers, managers, and labours at all levels lack adequate skills. At the same time, the education and training system lags far behind practical demand and it is even considered in crisis.

Weak infrastructure presents yet another constraint to long-term economic growth of the country. The bad transportation/logistic system and shortage of energy and transportation are impeding Vietnam's competitiveness and to a large extent, limiting the country in attracting both domestic and foreign investments. Resolving such problems is no easy task, as often complicated by inappropriate master planning and private-public partnership schemes, and poor "soft" infrastructure.

Finally, Vietnam has been facing higher macroeconomic and social risks as it integrates more deeply into the regional and world economy.

Deeper and wider integration may impose more constraints to policy choices, whilst exposing the country further to external shocks. This implies more complexity in resolving issues associated with macroeconomic management and various social pressures. Dealing with macroeconomic instability and social issues such as widening income/asset gap; emerging middle class; activity of vested groups, etc., thus becomes a multidimensional exercise, involving actions from economic, financial, social, and political stances.

From the policy perspective, policy-makers should also take into account a number of issues upon this era of post-WTO accession. It is very risky if the policy formulation process fails to follow closely the reality. The role of collecting, extracting, sharing and analysing information effectively should therefore be emphasized. Besides, as specific policy options can have unwanted side effects, it is essential to provide support groups of high vulnerability and to overcome vested groups. The "dosages" of macroeconomic policies, including monetary, fiscal, and exchange rate policies, in implementation should be considered carefully so as to achieve the desired results, without unfavorable changes in people's and investors' expectations. Effective coordination of these policies also deserves due attention, as the 
adjustment process often affect various aspects of the macroeconomic condition. Again, the macro policies need supplements from measures at the micro level to, for examples, support SMEs, poor people, etc.

The effectiveness of adjustment policies, in addition, rests heavily on public communication, as transparency and accountability of policymakers are key ingredients for public confidence and consensus. While policy adjustments are important, if not critical, enforcing policy reviewing mechanisms/institutions should be of great essence. For instance, those mechanisms/ institutions should rely on information and policy analysis, including policy choices and their impacts; forecasts and warnings; and cost-benefit analysis of large-scale public projects. They should also be independent, transparent with the wide-economy vision and professionalism. However challenging it may seem, the task for policy-makers should be no more than acquiring information and institutions for having better policy options, in combination with the "art" of implementing such policies.

\section{Concluding Remarks}

Over the two years 2007-2008, the changes in economic performance in Vietnam have been quite profound. This development partly confirms the gains anticipated prior to the country's accession to the WTO and further consolidates the optimism over its growth prospect. Deeper integration enhances the opportunities for growth and development, via broadening market access, strengthening competition, improving business and investment climate, and attracting FDI inflows. However, as previously discussed, actual economic development was significantly due to the interactions between various factors that have not been properly accounted for. Yet the country also becomes more vulnerable to external shocks as it gets more integral to the regional and the world economy, and the problems may be further complicated by the inappropriate (macro) policy responses/adjustment.

Nonetheless, both opportunities and challenges are interchangeable. Of utmost importance are the lessons that Vietnam has learned, and how the country strives to have suitable reform as well as appropriate policy responses. Further benefits from integration then requires acceleration of the structural reforms on large SOEs, financial supervision system, and independence of the State Bank of Vietnam. The current "bottlenecks" hindering sustainable development present another area for improvement which the country should be working on. Being further exposed to external shocks/changes, the country should pay more adequate attention to macroeconomic stabilization; yet the relevant macroeconomic policies will attain less than full effectiveness unless effective social supports are put in place. From a longerterm perspective, improvement of institutions, including institutions for policy implementation and better policy options, emerges as a critical need. Conditional on effective implementation, these measures should strengthen Vietnam's capacity in dealing with changes as its economic integration proceeds. 
APPENDIX 1

Vietnam's Tariffs Commitments under WTO by Major Sector

\begin{tabular}{lcc}
\hline & $\begin{array}{c}\text { Tariff at the time of } \\
\text { WTO admission (\%) }\end{array}$ & $\begin{array}{c}\text { Final tariff rate under } \\
\text { WTO commitments }(\%)\end{array}$ \\
\hline 1. Agricultural products & 25.2 & 21.0 \\
2. Fish and fishing products & 29.1 & 18.0 \\
3. Oils and gas & 36.8 & 36.6 \\
4. Wood and papers & 14.6 & 10.5 \\
5. Textile and garments & 13.7 & 13.7 \\
6. Leather and rubber & 19.1 & 14.6 \\
7. Metallic products & 14.8 & 11.4 \\
8. Chemical products & 11.1 & 6.9 \\
9. Transportation equipments & 46.9 & 37.4 \\
10. Mechanical machinery \& equipments & 9.2 & 7.3 \\
11. Electrical machinery \& equipments & 13.9 & 9.5 \\
12. Mining & 16.1 & 14.1 \\
13. Other manufacturing & 12.9 & 10.2 \\
\hline Overall & 17.2 & 13.4 \\
\hline
\end{tabular}

APPENDIX 2

Effective Rate of Protection (ERP) and Nominal Tariffs by Sector (\%)

\begin{tabular}{c|cccccccc}
\hline \multirow{2}{*}{ Year } & \multicolumn{2}{c}{ Agriculture \& Fisheries } & \multicolumn{2}{c}{ Mining \& gas } & \multicolumn{2}{c}{ Manufacturing } & \multicolumn{2}{l}{ Whole economy } \\
\cline { 2 - 9 } & ERP & Tariff & ERP & Tariff & ERP & Tariff & ERP & Tariff \\
\hline 2006 & 6.42 & 5.37 & 4.33 & 3.84 & 38.93 & 18.69 & 20.43 & 10.53 \\
2007 & 6.20 & 5.17 & 4.38 & 3.84 & 31.21 & 15.25 & 16.93 & 9.04 \\
2008 & 5.50 & 4.72 & 4.41 & 3.84 & 29.58 & 14.45 & 15.97 & 8.54 \\
2009 & 5.00 & 4.39 & 4.43 & 3.83 & 28.00 & 13.71 & 15.10 & 8.11 \\
2010 & 4.59 & 4.13 & 4.45 & 3.83 & 26.78 & 13.14 & 14.41 & 7.78 \\
2011 & 4.20 & 3.88 & 4.46 & 3.83 & 25.53 & 12.53 & 13.72 & 7.43 \\
2012 & 3.92 & 3.72 & 4.48 & 3.83 & 24.57 & 12.05 & 13.20 & 7.18 \\
2013 & 3.85 & 3.67 & 4.49 & 3.83 & 24.08 & 11.80 & 12.96 & 7.05 \\
2014 & 3.85 & 3.67 & 4.49 & 3.83 & 24.05 & 11.77 & 12.95 & 7.04 \\
2015 & 3.51 & 3.25 & -0.29 & 0.17 & 21.14 & 10.65 & 10.57 & 5.64 \\
2020 & 3.36 & 3.11 & -0.32 & 0.13 & 20.76 & 10.30 & 10.34 & 5.43 \\
\hline
\end{tabular}

NotE: ERPs' calculation is based on the assumption that the MNF tariff in 2006 will be applied if the bound tariff is higher than MFN.

Nominal tariff rate is estimated as the weighted average of tariffs, with the weights being sectoral value added.

Source: Cited from CIEM (2008a). 


\section{NOTES}

This article was first presented at an ISEAS conference, 30-31 October 2008. The opinions expressed in this paper are solely those of the authors and do not necessarily reflect the opinions of the Central Institute for Economic Management of Vietnam (CIEM).

1. In which US $\$ 1$ billion taken from the international reserves is used for interest rate subsidies, mostly for working capital borrowings by SMEs. Other supports are in the forms of profit tax exemptions/reductions and investments funded by bond issuing or external borrowings guaranteed by the Government.

2. As previously mentioned, this paper only focuses on the relevant research findings, without reviewing in greater details the pros and cons of concerned papers. For further references, a remarkable review of the studies on the WTO and integration impacts is that by Abbot, Bentzen, and Tarp (2007), CIEM (2008a), and Doan and Vo (2007).

3. See Abbot, Bentzen, and Tarp (2007) for an example. Doan and Vo (2007) notes that "Vietnam provides a strong case about the inability of the CGE-based approach in dealing with complex changes that are typical for a transitional economy. Barriers to trade have been only one of many market distortions, and arguably not the most decisive one (see also Appendixes 1 and 2 of Vietnam's tariff commitments and protection rates). Responses to regular firm surveys in Vietnam show a very high level of consensus on the most severe constraints facing firms over the years that consistently include shortage of capital, access to land, poor infrastructure and recently lack of skilled labour. Complexity of the distortions also implies the importance of getting the right sequence and pace of the reform measures... The CGE-based approach is yet to be able to deal with pace and sequence of reforms in an adequately way."

4. All data for 2008 , otherwise indicated, are of preliminary estimation.

5. Imports of machinery, source technology and supporting equipments from the United States, Japan and the European Union remain modest and tend to decline. Lacking access to source technology is still a prevalent issue, which may be detrimental to Vietnam's competitiveness in the long run.

6. The judgement is nearly the same if looking at its shares in real term (around 40 per cent).

7. The figures for the BOP in 2008 were projected in September 2008. Obviously the projection did not fully take into account the impacts of the global financial crisis. One fact is that during September-December 2008, foreign investors had a net selling of more than US $\$ 100$ million of shares and US\$1.6 billion of bonds in Vietnam securities markets (Dragon Capital 2009). The preliminary estimation in January 2009 indicates that the overall BOP in 2008 could be in deficit of US\$1-2 billion.

8. These figures are respectively 15.7 per cent and 15.0 per cent in 2005 and 21.8 per cent and 21.2 per cent in 2006 (Vo and Pham 2008).

\section{REFERENCES}

Abbot, P., J. Bentzen, and F. Tarp. "Trade and Development: Lessons from Vietnam's Past Trade Agreements". Discussion Paper 7/06, Department of Economics, University of Copenhagen, 2007.

Beyond WTO Design Team. "The Triggers for Moving to Phase II and The Possible Critical Issues for Phase II". Paper presented at the Workshop on the TOR for Phase II of the Beyond WTO Programs, Hanoi, 19 September 2008.

Central Institute for Economic Management (CIEM). "Impacts of International Integration, WTO Accession other bilateral and regional commitments - Appropriate Policy Measure Responses" (in Vietnamese). Report to the Government, Hanoi, January $2008 a$.

- "Impacts of International Integration on Vietnam Economy after 1.5 Years of WTO Admission" (in Vietnamese). Report to the Government, Hanoi, July $2008 b$.

Doan Hong Quang and Vo Tri Thanh. "Vietnam One Year after WTO Accession: A Review of Existing Studies and Preliminary Assessment". Paper presented at the PAFTAD 32, Hanoi, 17-19 December 2007.

Dragon Capital. "Vietnam's Financial Market". Report presented at the Conference on Global Financial Crisis: Challenges and Opportunities for Vietnam, Hanoi, 9 January 2009.

High Level Advisory Group (HLAG). "Institutional Arrangement for WTO Implementation (following the Gov't Resolution 16/2007/NQ-CP 16 February 2007)" (in Vietnamese). Hanoi, July 2008.

Nguyen Hai Huu, "Social safety net in the current macroeconomic situation". Paper presented at the Forum on Macroeconomic Stabilization: Challenges and Policy Options, organized by the CIEM and GTZ, Hanoi, 2 October 2008. 
Vo Tri Thanh and Pham Chi Quang. "Managing Capital Flows: The Case of Vietnam". ADBI Discussion Paper No. 105, May 2008.

Vo Tri Thanh is currently the Director of the Department for Trade Policy and International Integration Studies, Central Institute for Economic Management (CIEM), Vietnam.

Nguyen Anh Duong is a researcher at the Department for Trade Policy and International Integration Studies (CIEM). 